\title{
Factors Affecting Foreign Direct Investment in Ethiopia: ARDL Approach to Co-integration
}

\author{
Wuhib Seyoum \\ Lecturer, Department of Economics, College of Business and Economics, \\ Assosa University, Assosa, Ethiopia
}

\begin{abstract}
Different studies show that FDI has important roles to the economic development of a given country and it is determined by several factors. This study tried to investigate what critical factors are determining the amount of FDI inflow into Ethiopia. To accomplish the objective of the study a time series data ranging from 1981 up to 2016 is employed. The results of the Augmented Dickey Fuller (ADF) test indicate that the variables under consideration are a mixture of integrated of order zero and order one, that is, $\mathrm{I}(0)$ and $\mathrm{I}(1)$. Moreover, the result of bounds testing confirms the existence of stable long run relationship between FDI and its determinants. Accordingly, Autoregressive Distributed Lag (ARDL) model or bounds testing approach to co-integration and Error Correction Model (ECM) are applied to investigate the long run and short run relationship between FDI and its determinants respectively. The results of the study revealed that trade openness and real GDP positively influence the inflow of FDI while real effective exchange rate and government fiscal deficit have an adverse effect on FDI inflow. As a policy implication, it is recommended to dismantle restrictions on the free flow of capital, promote poverty alleviation strategies to enlarge the domestic market, strive to reduce budget deficit and avoid frequent changes in exchange rate.
\end{abstract}

Keywords: ARDL, Bounds testing, ECM, Ethiopia, FDI

DOI: $10.7176 / \mathrm{EJBM} / 12-35-02$

Publication date: December $31^{\text {st }} 2020$

\section{Introduction}

Nowadays it is observable that countries all over the world have interdependence in economic, political, and other social aspects. Looking at the economic aspect, the existence of international trade among nations plays a key role. Moreover, countries also create a relation among themselves through investment activities. Foreign direct investment is an investment which an investor from one nation invests his/her capital to another nation. This shows that the citizens of a given nation can participate in economic activities out of their nation boundary and contributing their capital for mutual benefit plus strengthening the economic relation. It is deep-rooted in economic growth theory that investment in capital is crucial to growth. New growth theories nowadays put emphasis on knowledge and technology as well. Countries lacking capital accumulation and technological progress are developing much slower than countries with high investment rate and large research and development expenditures. One way to fill this shortage in capital accumulation and technology could be through foreign direct investment. Foreign direct investment helps in not only filling the gap through transferring of capital and technology but also it integrates production processes and economic relation between countries around the globe (Douglas et al, 2003). In recent years, in LDCS, domestic resources are found to be inadequate to meet the financial requirements of economic development. They have too low level of capital formulation and any substantial increase in saving is not possible due to low level of income. Therefore, to overcome the retarding forces of rapid growth, the meager domestic savings are to be supplemented by imported capital (OECD, 2005).

As many economic growth theories explained, economic growth in any country depends on the sustained growth of productive capacity, supported by saving and investment. As a result most LDC governments saw FDI as a solution for their shortage of capital. The recognition of the role of knowledge capital in economic growth creates a basis for analyzing the determinants of FDI which brings new technology and knowledge along with capital. The effects of FDI can be wide ranging since it typically encompasses packages of capital as well as, technical, managerial and organizational know-how. FDI particularly is important for the LDCs since it provides access to resource that would otherwise be unavailable to these countries (Getinet and Hirut, 2006). The need to meet the objective of faster economic growth and low level of capital accumulation has conflicting nature. So to solve this problem FDI is served as a source of capital in most LDCs. In order to facilitate greater inflows in FDI, many LDCs have taken important steps to create a more favorable environment for foreign investment. Over the past decades market oriented policy reform in Ethiopia have placed a major emphasis to attract FDI.

Since 1991, the government of Ethiopia has made a board range of policy reforms including liberalization of foreign trade regime, decentralization of economic and political power, deregulation of domestic price and devaluation of the national currency. Moreover, the investment code has been amended several times in order to meet the demands of both domestic and foreign investors. A wide range of investment is believed to be the major requirement for sustainable development of a given country's economy. But in LDCs like Ethiopia where the 
majority of the population live below poverty line there is a chronic shortage of financial, physical as well as human capital to meet the desired level of investment in the economy. So there exists a wide gap between saving and investment due to low level of income and demotic saving (Getnet and Hirut, 2006). FDI as a source of capital and other business know - how is therefore desperately essential to finance growth and development.

Between 2000/01 and 2014/15, gross domestic investment as a proportion of GDP averaged 36.8\%, while gross domestic saving for the same period averaged 21.3\% (World Bank., 2018).This translates into an average saving- investment gap of $15.5 \%$ of GDP during the same period. Therefore, access to capital to fill this gap is more than necessity in these countries. To do so there should be capital inflow from other sources. Though there are various ways of foreign resource inflows, like aid, grants, loans, portfolio investment, etc., FDI is the one with better positive spillover effects. The government of Ethiopia has also realized the inadequacy of domestic capital and opened several economic sectors to foreign investors. The government has also issued several investment incentives including tax holidays, duty free importation of capital goods and export tax exemption to encourage private investment and promote the inflow of foreign capital and technology in to Ethiopia to both domestic and foreign investors, engaged in areas eligible for investment incentives. Therefore, this study is devoted to investigate the major determinants of FDI inflow into Ethiopia.

\section{Review of Related Literature}

Theories of FDI can be split into two groups: micro-level determinants of FDI and macro-level determinants of FDI. The micro-level theories of determinants of FDI try to provide answer the questions why multinational companies prefer opening subsidiaries in foreign countries rather than exporting or licensing their products, how MNCs choose their investment locations and why they invest where they do. The macro-level determinants deal with the host countries situations that determine the inflow of FDI. Among the micro level theories of FDI, theory of portfolio investment, Vernon's product life cycle theory (Vernon, 1966) and Dunning's eclectic theory of FDI (Dunning,1993) are worth mentioning. The theory of portfolio investment bases its explanation on interest rate differentials between countries. Capital, according to this explanation, moves in response to changes in interest rate differentials between countries/regions and multinational companies are simply viewed as arbitrageur of capital from countries where its return is low to countries where it is high. This explanation, however, fails to account for the cross movements of capital between/across countries. Vernon's product life cycle theory focuses on the role of innovation and economies of scale in determining trade patterns. It states that FDI is a stage in the life cycle of a new product from its invention to maturity. A new product is first manufactured in the home country for the home market. When the home market is saturated, the product is exported to other countries. At later stages, when the new product reaches maturity and loses its uniqueness, competition from similar rival products becomes more intense. At this stage producers would then look for lower cost foreign locations. This theory shows how market seeking and cost reduction motives of companies lead to FDI. Dunning's eclectic paradigm provides a general explanation for the determinants of FDI. Dunning (1993) identified three factors which must be satisfied before engaging in cross border activities, i.e., ownership advantage, internationalization advantage and location specific advantage. In Dunning's eclectic theory, the ownership and internalization advantages are firm specific features whilst the location advantages are country specific characteristics which the host country can influence directly. In general, countries that have location advantages can attract more FDI.

A great deal of empirical works have been done on this area. There are lots of evidences that revealed the size of host country market is important for foreign direct investment as it provides potential for local sales, greater profitability of local sales to export sales and relatively diverse resources, which make local sourcing more feasible (Root and Ahmed, 1979; Pefferman and Madarassy, 1992; Morisset, 2000; Chakrabarti, 2001; Getinet \& Hirut, 2006). Many studies also showed that trade openness has a positive impact in attracting FDI (Sing and Jun, 1995; Morisset, 2000; Chakrabarti; 2001; Bishwanath and Rashmi, 2007; Kabura, 2014). Similarly, the impacts of real effective exchange rate and government fiscal deficit are well documented in different literatures (Pefferman and Madarassy, 1992; Accolley et al, 1997; Chakrabarti, 2001; Salisu, 2003).

\section{Data source and Variable Description}

The study entirely relied on secondary data sources. The time series data ranging from the period 1981 to 2016 is collected from National Bank of Ethiopia (NBE), Ministry of Finance and Economic Cooperation (MoFEC), Central Statistical Agency (CSA) of Ethiopia, as well as the databases of International Monetary Fund (IMF) and World Bank (WB).

The working definitions of the explanatory variables, their respective causal relationship with the dependent variable and expected sign are summarized hereunder. 
Table 3.1 Summary of definition of explanatory variables and respective expected sign

\section{Variables Description and relation with FDI}

\begin{tabular}{|c|c|c|}
\hline $\begin{array}{l}\text { Degree } \\
\text { openness }\end{array}$ & $\begin{array}{l}\text { In this study export and import as a percentage of GDP is used to } \\
\text { measure degree of openness. For export oriented companies openness } \\
\text { promotes FDI. Countries that are more open to trade (i.e. have a high } \\
\text { ratio between the sum of export and import and GDP) tends to attract } \\
\text { more FDI. }\end{array}$ & Positive \\
\hline $\begin{array}{l}\text { Real Effective } \\
\text { Exchange Rate }\end{array}$ & $\begin{array}{l}\text { Weighted average of the Real Exchange Rate to the currencies of } \\
\text { its trading partners adjusted by the weights of trading partners. } \\
\text { Basically, the decline in the value of domestic currency interns of } \\
\text { foreign currency tends to attract more FDI and vice versa. }\end{array}$ & Negative \\
\hline Market Size & $\begin{array}{l}\text { Measured by the value of total goods and services produced in a given } \\
\text { year at constant price, real GDP is included in the regression analysis } \\
\text { as a measure of market size. A large market can help firms producing } \\
\text { tangible products to achieve scale and scope economies. }\end{array}$ & Positive \\
\hline Inflation & $\begin{array}{l}\text { A sustained increase in the general price of goods and services in the } \\
\text { economy, based on CPI. It is used to measure the effect of } \\
\text { macroeconomic stability and low inflation is expected to have a } \\
\text { positive marginal influence on FDI inflow. }\end{array}$ & Negative \\
\hline Fiscal Deficit & $\begin{array}{l}\text { The difference between government revenue and its expenditure. } \\
\text { High government fiscal deficits, financed through domestic } \\
\text { borrowing, affect the amount of credit available for the private sector } \\
\text { by raising interest rates and hence the cost of borrowing; and it } \\
\text { reduces the amount of credit available to the private sector. This } \\
\text { would discourage foreign investors. }\end{array}$ & Negative \\
\hline
\end{tabular}

\section{Methodology and Model Specification}

For investigating the long-run equilibrium (cointegration) among time-series variables, several econometric methods are proposed in the last two decades. Univariate cointegration examples include Engle and Granger (1987) and the fully modified OLS procedures of Phillips and Hansen's (1990). With regards to multivariate cointegration, Johansen (1988) and Johansen and Juselius (1990) procedures and Johansen's (1996) full information maximum likelihood procedures are widely used in empirical research (Halicioglu, 2004).

The autoregressive distributed lag (ARDL) also deals with single cointegration and is introduced originally by Pesaran and Shin (1999) and further extended by Pesaran et al. (2001). As it was cited in Wuhib (2020), ARDL approach has certain econometric advantages in comparison to other single cointegration procedures. Firstly, endogeneity problems and inability to test hypotheses on the estimated coefficients in the long-run associated with the Engle-Granger method are avoided. Secondly, the long and short-run parameters of the model are estimated simultaneously. Thirdly, all variables are assumed to be endogenous. Fourthly, the econometric methodology is relieved of the burden of establishing the order of integration amongst the variables and of pre-testing for unit roots. In fact, whereas all other methods require that the variables in a time-series regression equation are integrated of order one, i.e., the variables are I(1), only that of Pesaran et al. (2001) could be implemented regardless of whether the underlying variables are $\mathrm{I}(0), \mathrm{I}(1)$, or fractionally integrated.

In line with theoretical and empirical literatures, FDI as a function of its determinants, among others, can be specified as follows.

$$
F D I G_{t}=\lambda_{0}+\lambda_{1} O P E N_{t}+\lambda_{2} R E E R_{t}+\lambda_{g} l n R G D P_{t}+\lambda_{4} I N F_{t}+\lambda_{5} F D G_{t}+s_{t} \ldots \ldots . .1
$$

Where $\lambda_{0}$ is the intercept term,

$\lambda_{1} \ldots \lambda_{5}$ are the coefficients of the explanatory variables and $\varepsilon_{\mathrm{t}}$ is the white noise error term a prefix ln denotes natural logarithms of the subsequent variables, FDIG= foreign direct investment as a share of GDP, OPEN = trade openness, REER = real effective exchange rate, lnRGDP $=$ natural logarithm of real GDP, INF $=$ Inflation rate and FDG $=$ government fiscal deficit as a share of GDP

The ARDL approach to co-integration involves estimating the error correction model (ECM) version of ARDL model for the determinants of current account balance. 


$$
\begin{aligned}
\Delta F D F G_{t}= & \beta_{0}+\sum_{t=1}^{m} \beta_{1 t} \Delta F D I G_{t-t}+\sum_{t=0}^{m} \beta_{2 t} \Delta O P E N_{t-t}+\sum_{t=0}^{m} \beta_{3 t t} \Delta R E E R_{t-t} \\
& +\sum_{t=0}^{m} \beta_{4 t} \Delta l n R G D P_{t-t}+\sum_{t=0}^{m} \beta_{6 t i} \Delta I N F_{t-1}+\sum_{t=0}^{m} \beta_{G t} \Delta F D G_{t-t}+\delta_{1} F D I G_{t-1} \\
& +\delta_{2} O P E N_{t-1}+\delta_{3} R E E R_{t-1}+\delta_{4} l n R G D P_{t-1}+\delta_{6} I N F_{t-1}+\delta_{6} F D G_{t-1}+s_{t}
\end{aligned}
$$

where, $\Delta$ is first difference operator, $\boldsymbol{\delta}, \mathrm{i}=1 \ldots \ldots .6$ are long run coefficients and $\boldsymbol{\beta}, 1 \ldots . .6$ are the short run dynamic coefficients of the ARDL. All the variables are as previously defined. The above model will be estimated using OLS for the purpose of testing long run relationship.

Investigation of the presence of a long-run relationship amongst the variables of Eq. (1) is tested by means of bounds testing procedure. The bounds testing procedure is based on the F or Wald-statistics and is the first stage of the ARDL cointegration method. Accordingly, a joint significance test that implies no cointegration, $\left(\mathrm{H}_{0}: \boldsymbol{\delta}_{1}=\right.$ $\boldsymbol{\delta}_{2}=\boldsymbol{\delta}_{3}=\boldsymbol{\delta}_{4}=\boldsymbol{\delta}_{5}=\boldsymbol{\delta}_{6}=0$ ), should be performed for Eq. (2). The F test used for this procedure has a non-standard distribution. Thus, two sets of critical values are computed for a given significance level. One set assumes that all variables are I $(0)$ and the other set assumes they are all I(1). If the computed F-statistics is larger than the upper bound critical value, then the null hypothesis of no long run relationship is rejected in favor of the alternative hypothesis that there exists a long run relationship. But, if the computed F-statistics is less than the lower bound critical values the null hypothesis is accepted showing that there is no long run relationship. At last, if the computed F-statistics lies between the lower and the upper bound critical values, inference is inconclusive and we have to determine the order of integration of the regressors prior to making conclusive inference (pesaran et al.,2001).

After identification of a long-run relationship between variables, then short- run dynamic of the model can be obtained by estimating an error correction model (ECM) associated with the long-run estimates. This also indicates the speed of adjustment back to long-run equilibrium after a short-run shock. The standard ECM involves estimating the following equation.

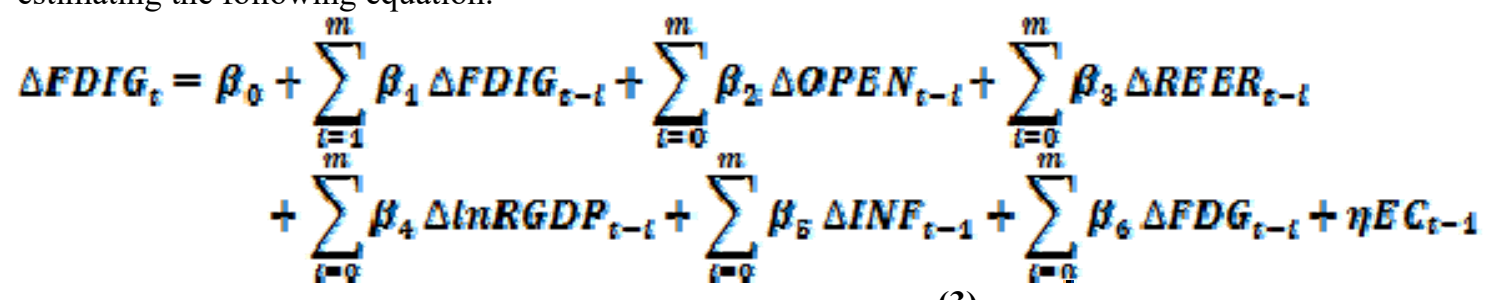

where $\boldsymbol{\beta}_{1} \ldots . . \boldsymbol{\beta}_{7}$ are the short run dynamic coefficient of the variables in the model, $\mathrm{EC}_{\mathrm{t}-1}$ is the error correction term which is obtained from ARDL long run dynamics of the model. The coefficient of $\mathrm{EC}_{\mathrm{t}-1}$ indicates the speed of adjustment to bring back equilibrium in the model. Moreover, it is expected to have a negative sign, showing the variables converge to the equilibrium. 


\section{Discussion of Empirical Results}

5.1 Unit root test results using ADF test

Table 5.1 Unit root test results using ADF test

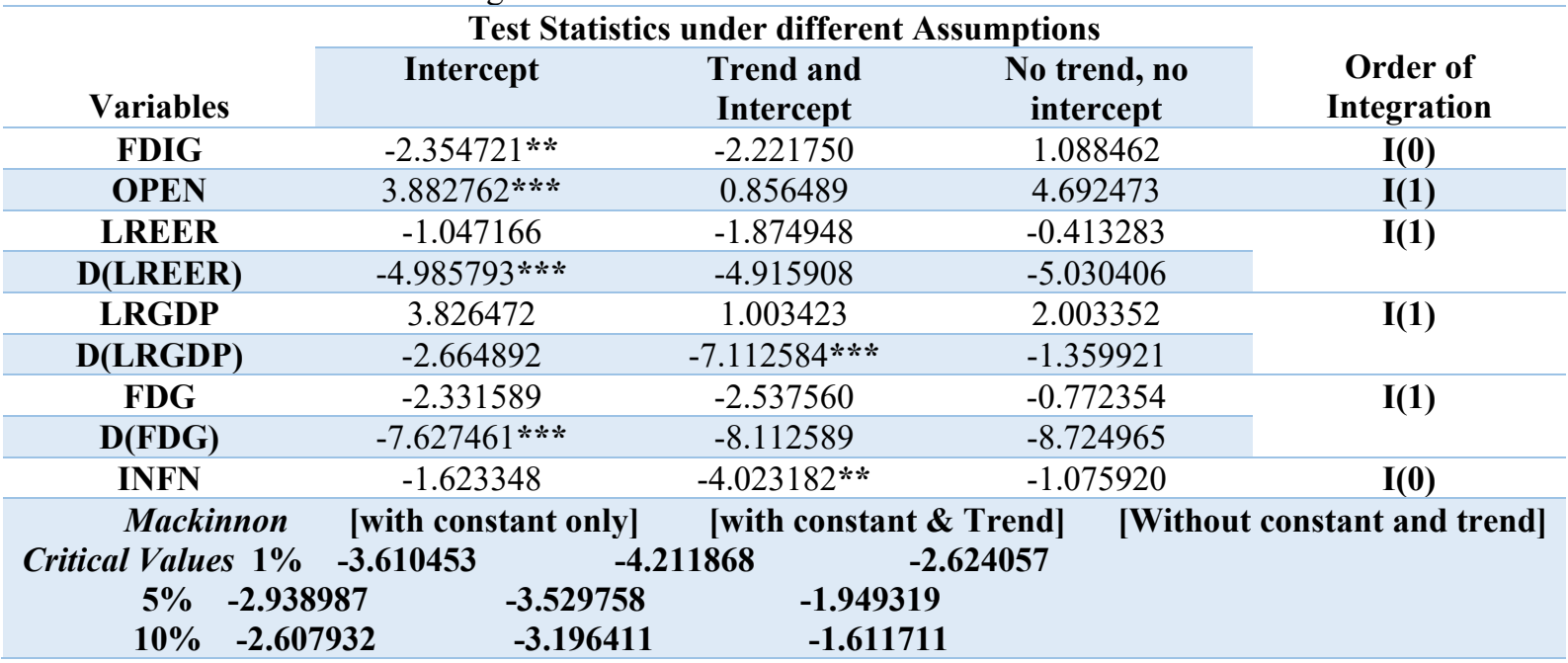

The above table shows that the variables under consideration are a mixture integrated of order one and integrated of order two, i.e., I(0) and I(1) which guarantees the appropriateness of employing ARDL approach to cointegration or bounds testing approach to check the long run relationship among the variables.

\subsection{Test for Long Run Relationship (Bounds Testing to Co-integration)}

The critical values used for bounds test for the respective number of regressors (5) are given below. Table 5.2 The critical values for bound test for the case with unrestricted intercept and no trend

\begin{tabular}{|c|c|c|c|c|c|c|}
\hline & \multicolumn{2}{|c|}{1 percent } & \multicolumn{2}{|c|}{5 percent } & \multicolumn{2}{|c|}{10 percent } \\
\hline$K$ & $I(0)$ & $I(1)$ & $I(0)$ & $I(1)$ & $I(0)$ & $I(1)$ \\
\hline 5 & 3.41 & 4.68 & 2.62 & 3.79 & 2.26 & 3.35 \\
\hline
\end{tabular}

\section{Source: Pesaran et al. (2001)}

Note: $\mathrm{I}(0)$ and $\mathrm{I}(1)$ denote upper bound and lower bound values respectively.

The calculated F-statistic resulted from the F-test or the Wald-test to check the joint significance of the coefficients is found to be (4.835763). Since the calculated F-statistic (4.835763) is larger than the critical values for bound test at all levels of significance, it implies that the null hypothesis of no co-integration is strongly rejected in favor of the alternative hypothesis of there is co-integration. This proved that there is a long run relationship among the variables of interest.

\subsection{Estimation of Long Run ARDL Model}

The next step after realizing the existence of long run relationship among the variables, is estimating the long run ARDL model for the determinants of FDI.

Table 5.3 Estimated Long Run Coefficients using the ARDL Approach ARDL $(1,1,2,1,2,3)$ based on Akaike information criteria

\begin{tabular}{|c|c|c|c|c|}
\hline \multicolumn{5}{|c|}{ The dependent variable is FDIG } \\
\hline Regressors & Coefficient & Standard Error & T-Ratio & P-Values \\
\hline OPEN & $0.209598 * * *$ & 0.107280 & 1.953747 & 0.0023 \\
\hline LREER & $-0.110718 * * *$ & 0.054083 & -2.047300 & 0.0075 \\
\hline LRGDP & $0.440613 * *$ & 0.251810 & 1.749783 & 0.0253 \\
\hline FDG & $-0.239871 * * *$ & 0.064363 & -3.726846 & 0.0028 \\
\hline INFN & -0.001658 & 0.006796 & -0.243967 & 0.2764 \\
\hline Constant & $2.758933 * *$ & 0.994521 & 2.774132 & 0.0368 \\
\hline $\begin{array}{l}\mathbf{R}^{2}=0.58105 \\
\text { Adjusted-R }\end{array}$ & \multicolumn{4}{|c|}{ F-Statistics $(5,28)=55.576[0.000]$} \\
\hline
\end{tabular}

\section{Source: Eviews 9 ARDL $(1,1,2,1,2,3)$ output}

Note: $* * *$ and $* *$ denote significance at $1 \%$ and $5 \%$ respectively

As it can be seen from the above table, except inflation, all the estimated coefficients are found statistically significant and their direction of influence is appeared to be consistent with the predictions of the theoretical as well as empirical literatures.

The empirical result of long run ARDL estimation presented in table 5.3 revealed that, trade openness and 
real GDP which is used to capture the market size have a positive and significant influence on FDI inflow in Ethiopia. Accordingly, a one percentage increase in openness and real GDP brought a 0.20 and 0.44 percentage point improvement in FDI inflow respectively. The result of this study coincides with that of (Root and Ahmed, 1979; Pefferman and Madarassy, 1992; Morisset, 2000; Chakrabarti, 2001; Getinet \& Hirut, 2006). The results also reflect the significant and negative effect of real effective exchange rate and government fiscal deficit on FDI in the sense that, a $1 \%$ increase in real effective exchange rate and fiscal deficit tends to bring a 0.11 and 0.23 percentage points decline in FDI, respectively. These results are consistent with the results found by most of the studies in the existing empirical literature including (Pefferman and Madarassy, 1992; Accolley et al, 1997; Chakrabarti, 2001; Salisu, 2003). Moreover, inflation appeared to be insignificant meaning it has no meaningful influence to determine the inflow of FDI in the country.

\subsection{Estimation of Short run model (Error Correction Model)}

The next step is estimating error correction model to predict the short run coefficients. The coefficient of the error correction term indicates the speed of adjustment to restore equilibrium in the dynamic model. It is a one lagged period residual obtained from the estimated dynamic long run model. Moreover, it is expected to be statistically significant having a negative sign, showing that the variables converge to the equilibrium.

Table 5.4 Error Correction Representation for the Selected ARDL $(1,1,2,1,2,3)$ selected based on Akaike Information Criterion.

\begin{tabular}{|l|c|c|c|c|}
\hline \multicolumn{4}{c}{ The dependent variable is DFDIG } \\
\hline \multicolumn{1}{|c|}{ Regressors } & Coefficient & Standard Error & T-Ratio & P-Values \\
\hline D(OPEN) & 0.2434 & 0.1271 & 1.9150 & 0.0354 \\
\hline D(LREER(-1)) & -0.7750 & 0.3537 & -2.1911 & 0.0062 \\
\hline D(LRGDP) & 0.1320 & 0.0422 & 3.1279 & 0.0452 \\
\hline D(BBG(-1)) & -0.0081 & 0.0020 & -4.0500 & 0.0037 \\
\hline D(INFN(-2)) & -0.0354 & 0.0214 & -1.6542 & 0.1103 \\
\hline ECt-1 & -0.5335 & 0.2540 & -2.1003 & 0.0000 \\
\hline $\mathbf{R}^{\mathbf{2}=\mathbf{0 . 5 2 8 9 7}}$ & F-stat. F (10, 27) $\mathbf{1 2 . 9 2 9 0 [ . 0 0 0}$ & & \\
Adjusted $\mathbf{R}^{\mathbf{2}}=\mathbf{0 . 5 1 5 0 4}$ & DW-statistic $=\mathbf{2 . 2 5 1 8}$ & & \\
\hline
\end{tabular}

Source: Eviews 9 output

ECM results are similar to the results of cointegration relationship among variables, except that the short-run dynamics among variables suggest a less powerful effect of variables on FDI. The error correction term $\mathrm{EC}_{\mathrm{t}-1}$, which measures the speed of adjustment to restore equilibrium in the dynamic model, appears with negative sign as expected and it is strongly significant at a 1 percent level, ensuring that the long-run equilibrium can be attained. As shown above the coefficient of $\mathrm{EC}_{\mathrm{t}-1}$ is -0.53 showing that the speed of adjustment to the long -run equilibrium after a shock has been happened is 53\%. That is; about 53\% of disequilibria from the previous year's shock can be corrected to the long run equilibrium in the current year. Moreover, it implies that it took almost two years to eliminate the disequilibrium and come back to a full adjustment towards its long run equilibrium.

\subsection{Results of Model Stability and Diagnostic Tests}

To check the standard properties of the model, this study carried a number of model stability and diagnostic checking, which include Serial correlation test (Brush \& Godfray LM test), Functional form (Ramsey's RESET) test, Normality (Jarque-Bera test), and Hetroskedasticity test.

Table 5.5 Diagnostic tests for long run ARDL $(1,1,2,1,2,3)$

\begin{tabular}{|c|c|}
\hline Test Statistics & F/Chi square Version \\
\hline A: Serial Correlation & $F(1,28)=1.6786[0.206]$ \\
\hline B: Functional Form & $F(1,28)=0.38635[0.539]$ \\
\hline C: Normality & $\mathrm{CHSQ}(2)=1.2932[0.524]$ \\
\hline D: Hetroscedasticity & $\mathrm{F}(1,36)=.038642[0.845]$ \\
\hline \multicolumn{2}{|c|}{$\begin{array}{l}\text { A: Lagrange multiplier test of residual serial correlation } \\
\text { B: Ramsey's RESET test using the square of the fitted values } \\
\text { C: Based on a test of skewness and kurtosis of residuals } \\
\text { D: Based on the regression of squared residuals on squared fitted values }\end{array}$} \\
\hline
\end{tabular}

As can be seen from table 5.5 the model passes all the diagnostic tests against serial correlation, heteroscedasticity, and normality of errors. The Ramsey RESET test also suggests that the model is well specified.

In addition to the above diagnostic tests, the stability of long run estimates has been tested by applying the cumulative sum of recursive residuals (CUSUM) and the cumulative sum of squares of recursive residuals (CUSUMSQ) test. The stability of the long-run coefficient is tested by the short-run dynamics. Once the Error 
correction model has been estimated the cumulative sum of recursive residuals (CUSUM) and the CUSUM of square (CUSUMSQ) is applied to assess the parameter stability (Pesaran, 1997). The results indicate the absence of any instability of the coefficients because the plot of the CUSUM statistic and the CUSUM of square (CUSUMSQ) fall inside the critical bounds of the 5\% confidence interval of parameter stability.

\section{Concluding remarks and Policy Implications}

The main objective of this study is to empirically investigate the long run and short run relationship between inflow of foreign direct investment and its main determinants in Ethiopia by using time series data ranging from 19812016. In this study, Autoregressive Distributed Lag (ARDL) model or bounds testing approach to co-integration and Error Correction Model are applied to determine the long run and short run relationship among the variables, respectively.

According to the empirical result of long run ARDL estimation, trade openness and real GDP are found to have positive and significant influence on FDI. Whereas real effective exchange rate and government fiscal deficit have a negative and significant impact on FDI.

Based on the findings of this study, the following policy recommendations are forwarded to increase the inflow of FDI in Ethiopia.

$\Rightarrow$ The positive and significant coefficient of trade openness signifies the crucial role of the degree to which the country is open for foreign trade in stimulating the inflow of foreign investment. So the government should strive in dismantling restrictions that could prohibit the free flow of capital.

$\overrightarrow{0}$ The positive and significant effect of market size on foreign direct investment emphasizes the essential role of economic growth and expanded market opportunities in stimulating foreign direct investment. Accordingly, the government should promote poverty alleviation strategies that could also foster economic growth.

$\overrightarrow{0}$ The significantly negative coefficient of government budget deficit variable highlights the need for reducing fiscal deficits that could implicate higher future taxes to finance them and increase the likelihood of additional tax burden for foreign investors.

$\overrightarrow{0}$ The empirical results indicate the existence of negative long run relationship between real effective exchange rate and FDI inflow. This showed that devaluation of host country's currency will deter the country's effort in attracting FDI inflow. Consequently, the government should avoid frequent volatility of domestic currency in order not to adversely affect the confidence of foreign investors.

\section{References}

Accolley D. and Perlam J. (1997). The determinants and impact of Foreign Direct Investment. London Metropolitan University, London

Bishwanath G. and Rashmi B. (2007). Impact of Trade Liberalization on Foreign Direct Investment in Indian Industries, ARTNeT Working Paper Series, No. 36, Asia-Pacific Research and Training Network on Trade (ARTNeT), Bangkok

Carlos and Eddie (2015). Foreign direct investment and gross domestic product growth. International Conference on Applied Economics, ICOAE 2015, 2-4 July 2015, Kazan, Russia. Procedia Economics and Finance 24, $198-207$.

Chakrabarti A. (2001). The Determinants of Foreign Direct Investment: Sensitivity Analyses of Cross-Country Regressions, KYKLOS, 54, pp. 89-114

Douglas H., Emma F., Lea R. (2003). Foreign direct investment in developing Asia: Trends, effects, and likely issues for the forthcoming WTO negotiations. Asian Development Bank.

Dunning, J.H (1993). Multinational Enterprises and the Global Economy. Wokingham, England: Addison-Wesley

Engle, R. and Granger, C. (1987). Cointegration and error correction representation: estimation and testing. Econometrica, 55, pp.251-276.

Getinet H. and Hirut A. (2006). Determinants of Foreign Direct Investment in Ethiopia: a time series analysis. University of Westminster.

Halicioglu, F. (2004). An ARDL Model of International Tourist Flows to Turkey. Global Business and Economics Review 2004 Anthology, pp.614-624

Johansen, S. (1996). Likelihood-Based Inference in Cointegrated Vector Auto-Regressive Models 2nd edn. (Oxford; Oxford University Press,)

Johansen, S. and Juselius, K. (1990). Maximum likelihood estimation and inference on cointegration -with application to the demand for money. Oxford Bulletin of Economics and Statistics, Vol. 52, , pp.169-210.

Kabura G. (2014). The Relationship between Exchange Rates and Foreign Direct Investment in Kenya". Unpublished MBA Thesis. University of Nairobi.

Morisset, J. (2001). Foreign Direct Investment in Africa: Policies Also matter. Transnational Corporation, 9(2), $107-125$ 
OECD (2005). Investment for African Development: Making it Happen. NEPAD/ OECD Investment Initiative.

Pefferman, G.P. and Madarassy, A (1992). Trends in Private Investment in Developing Countries, 1992 edition, International Finance Cooperation, Discussion Paper No.14, Washington D.C.

Pesaran, M. and Shin, Y. (1999). An Autoregressive Distributed Lag Modeling Approach to Cointegration Analysis, in S. Strom, Econometrics and Economic Theory in the 20th Century: The Ragnar Frisch centennial Symposium, Cambridge University Press, Cambridge.

Pesaran, M., Shin,Y. \& Smith, R.J. (2001). "Bounds Testing Approaches to the Analysis of level Relationships". Journal of Applied Econometrics (16):289-326

Phillips, P. and Hansen, B. (1990). Statistical inference in instrumental variables regression with I(1) process. Review of Economic Studies, 57, pp.99-125.

Root, F. \& Ahmed A. (1979). Empirical Determinants of Manufacturing Direct Foreign Investment in Developing Countries. Economic Development and Cultural Change, 27: 751-767.

Salisu, M. (2003). Foreign Direct Investment in Sub-Saharan Africa. The Management School, Lancaster University.

Singh H., and Jun W. (1995). Some New Evidence on the Determinants of Foreign Direct Investment in Developing Countries. The World Bank Policy Research Working Paper, No, 1531

Vernon, R. (1966). International investment and international trade in the product cycle, Quarterly Journal of Economics, 80: 255-267

World Bank (2018). World Bank National Accounts data

Wuhib S. (2020). Determinants of Current Account Deficit: Empirical Evidence from Ethiopia. Research Journal of Finance and Accounting, 11, (17): 56-65 